\title{
TEXTOS PRIMITIVOS DA FRANXA ORIENTAL ${ }^{1}$
}

\author{
Raquel Rodríguez Parada
}

Instituto da Lingua Galega (USC)

\begin{abstract}
...no sólo alcanzaba el idioma gallego hasta Lamego, por lo que hoy son tierras portuguesas, sino que en Asturias, León y Zamora era tan usual, que aún hoy se conserva en algunas comarcas de aquellas provincias, y los actuales dialectos leoneses guardan el sello de la pasada influencia. El bable de occidente conserva muchisimas voces gallegas... También en la Puebla de Sanabria persisten gran número de voces...
\end{abstract}

Leandro Carré Alvarellos, El idioma gallego en la Edad Media (1973)

O traballo que presentamos ten como finalidade ofrecer unha visión xeral dos textos galegos da franxa oriental. Para comezarmos temos que establecer unha distinción entre textos literarios e textos históricos e centrarémonos exclusivamente nestes últimos, pois presentan máis heteroxeneidade ca os literarios.

Por cuestións metodolóxicas e dado a época que estudamos, falaremos de astur-leonés para referírmonos ao dominio lingüístico que se estendía polas actuais provincias de Asturias e León, seguindo así a denominación empregada por García Arias (1995: 619).

O corpus do que partimos está formado por versións a lgunhas delas incompletas- de catro obras en prosa histórica, polos foros de Castelo Rodrigo e mais por 49 documentos notariais, aos que accedemos a través de lecturas feitas por historiadores ${ }^{2}$. Cómpre advertir disto, pois somos cons-

1. O noso agradecemento a Ana Boullón, polas súas suxestións, e a Luz Méndez, por darnos a coñecer textos da franxa dos que non tiñamos constancia.

2. A revisión da lectura, o cotexo co documento orixinal á s veces, copias- e as pertinentes emendas serán recollidas na miña tese de doutoramento, Documentos notariais en galego do século XIII. Edición e estudo lingüístico, hoxe en curso de realización. Tamén daremos conta, máis polo miúdo, do estado do romance na área fronteiriza astur-leonesa. 
cientes de que o grao de fiabilidade que nos dan estas lecturas non é o suficientemente alto, ben debido á heteroxeneidade de criterios empregados polos diversos editores, ben debido ao pouco rigor e interese co que se fan, en moitos casos, as transcricións em itindo o desenvolvemento das abreviaturas, etc.

O marco cronolóxico ao que pertencen os documentos xurídicos abrangue dende finais dos anos vinte do século XIII ata o ano 1260 —inclusivepor ser a data en que se incrementa o uso do romance nas escrituras; é a partir de aquí cando a produción documental en lingua galega se xeneraliza ao poñerse por escrito a lingua que falaba a poboación. O gráfico que segue ilustra este incremento da produción textual no noso corpus:

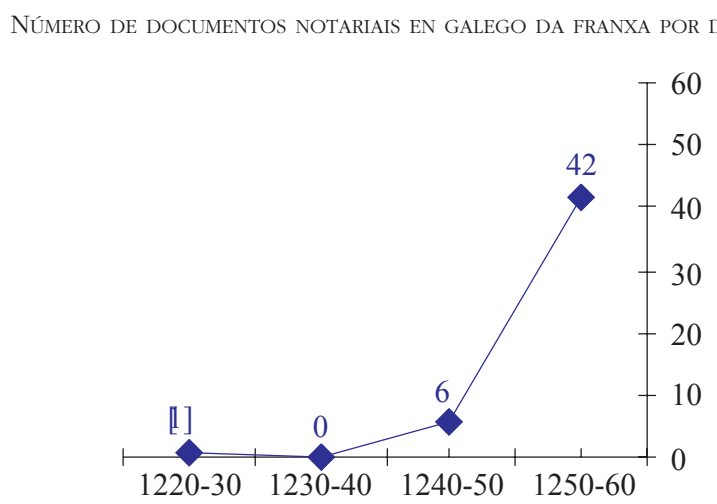

Dende a actualidade, intentar adscribir lingüisticamente moitos dos textos do corpus á área galega ou astur-leonesa non é unha tarefa fácil e, como consecuencia, calquera tentativa para o estudo deste tipo de documentos da franxa vai ser tratada con moita cautela.

\section{A CONFORMACIÓN DA SOCIEDADE GALEGA NO SÉCULO XIII}

Para estudar o galego nos textos primitivos da franxa oriental debemos ter presente que as fronteiras actuais non coinciden coas existentes no proceso de conformación do idioma e están condicionadas polos acontecementos histórico-políticos.

Coa chegada dos árabes á Península Ibérica prodúcese a fragmentación da Hispania entre os territorios cristiáns do norte e os que estaban baixo o dominio musulmán no centro e sur. A ocupación islámica dos territorios do sur reforzou a unidade entre os principados cristiáns situados no centro e 
norte peninsular e, como consecuencia, Galicia, cunha feble invasión árabe, estivo vencellada á coroa galego-astur-leonesa dende finais do século XI ata mediados do XII, momento en que esa unidade comeza a desfragmentarse: por un lado o reino de Portugal (a. 1140), por outro o conxunto galego-astur-leonés e, finalmente, o castelán.

Durante os séculos en que se mantivo unida a coroa houbo unha serie de feitos que trazaron a historia política galega e peninsular. A sociedade galega no século XII presenciou o nacemento da poboación urbana e o aumento de poder e consolidación da nobreza. É o momento en que a cidade compostelá experimentou un gran cambio social marcado polo aumento das peregrinacións e pola promoción cultural levada a cabo polo bispo Xelmírez. Na península, o reino astur-leonés vai perdendo autonomía, destacan as relacións entre a España cristiá e Galicia e a inversión do equilibrio de forzas e poder entre o sur islámico e o norte cristián, a favor deste último.

A independencia do reino galego-leonés rematou en 1230 co reinado de Fernando III o Santo, que uniu as coroas de Galicia, León e Castela e estendeu os seus dominios cara ao sur peninsular. Neste período o monarca comezou a introducir o castelán no ámbito xurídico-administrativo, medida que se viu referendada durante o reinado de Afonso x (1252-1284) e os seus sucesores, que ante a heteroxeneidade lingüística dos dominios da coroa —vasco, astur-leonés, galego, castelán e árabe- estableceron o uso do romance castelá na chancelaría real.

No século XII Galicia aínda posúe unha grande autonomía, malia non ser un reino independente, grazas ao proceso de urbanización e ao nacemento da nobreza como nova clase social (Pallares 1987). A separación política entre Galicia e o país veciño a finais do século XI, coa conseguinte creación do reino de Portugal na primeira metade do XII, aínda non ten repercusión lingüística e a unidade entre Galicia e norte de Portugal segue existindo; o galego séguese falando, pero a separación entre o Miño e a zona entre o Douro e o Miño e o centro e o sur de Portugal é cada vez maior. Galicia, por unha banda, e Portugal, pola outra, van fixando unha variedade escrita e como proba está a rica lírica trobadoresca ${ }^{3} €$ un corpus de 1.679 cantigas (Tavani 1991: 191)_ á que lle podemos engadir, aínda que con moito menor cultivo, a prosa de carácter literario, histórico ou xurídico (Monteagudo 1994b: 175-6). Os acontecementos políticos que se produciron entre a metade do século XIV e o remate do Xv foron decisivos para a introdución do castelán en Galicia.

3. Esa rica produción é analizada por Tavani (19913) e pode lerse unha síntese (2004[2005]) no discurso lido na sé da Real Academia Galega no acto da súa recepción como académico de honra, o 22 de maio de 2004 . 
Polo tanto, no século xiII, que ocupa a nosa atención, o binomio fronteiras lingüísticas-fronteiras políticas non existía, tratábase dunha serie de falas neolatinas percibidas como modalidade dunha única lingua que variaba dunha terra a outra. Existía un contexto plurilingüe en que convivía o latín, a lingua da escrita, e as falas de transición que se agrupaban atendendo a criterios máis xeográficos ou étnicos ca lingüísticos. A chegada do século XIII supón, aínda que cun trazo moi difuminado, o comezo no espreitar da consciencia dos distintos romances (Monteagudo 2004b: 52-60) e é o momento en que o galego comeza a agromar, timidamente, na escrita ${ }^{4}$.

Esta época, caracterizada pola difusividade lingüística e por ser o momento en que o romance escrito se está xestando lentamente, temos documentos notariais e traducións de prosa histórica en que conviven trazos galegos e astur-leoneses, que constitúen unha extraordinaria fonte para o estudo da lingua. A esta hibridación nos textos galegos facía referencia Maia (1986: 932):

Na Galiza, onde os documentos parecem reflectir mais intensamente particularidades da linguagem falada, destacaram-se também alguns elementos comprovativos de uma sensível diversificação regional já durante o período abrangido pelo presentente estudo [do séc. XIII ao xvI]. É evidente que não se pretende delimitar claramente determinadas sub-regiões galegas, mas apenas chamar a atención para a singularidade de algumas zonas que, de acordo con o estudo realizado, tinham uma tonalidade dialectal característica e distinta da de outras zonas galegas.

\section{Descrición dos teXtos Galegos DA FRANXA: ¿ANTE QUEM?}

A continuación daremos conta dalgúns textos galegos da fronteira caracterizados por presentar un conxunto de características lingüísticas a camiño entre romance galego e astur-leonés. Somos conscientes de que nesta selección terían cabida moitos máis textos que presentan menos características lingüísticas ca os recollidos aquí, onde damos conta daqueles que, baixo a nosa óptica, son os máis significativos.

No que respecta ao uso do galego no ámbito da xustiza, consérvanse fragmentos traducidos de catro tratados xurídicos da época: o Forum Iudi-

4. Nos cancioneiros galego-portugueses rexistramos composicións en galego dende comezos do século XIII (Tavani 1991: 11), pero nos documentos notariais a forte eclosión do galego data da segunda metade do século XIII. 
cum, as Flores de Dereito, as Partidas e o Foro Real, os dous últimos de Afonso x. Non menos coñecidos son os foros de Castelo Rodrigo, editados por Lindley Cintra (1959) baixo o subtítulo de Contribuição para o estudo do leonês e do galego português do século XIII.

Como complemento da relación anterior, no noso corpus documental recollemos textos notariais que tamén presentan trazos lingüísticos propios da franxa oriental. O primeiro deles, pertencente á documentación do mosteiro de Melón, é coñecido como tombo das viñas de Ribadavia, que se adscribe hipoteticamente ao ano 1228 (Ferro Couselo 1957: 8), pois non ten data 5 está parte en leonés e parte en galego (Lorenzo 2004b: 38). Ademais, en Galicia contamos cun texto de 1244 pertencente á documentación do convento de Santa Clara de Allariz (Ferro Couselo 1967: 13-14). Menos problemas na datación teñen os documentos transcritos no tombo de San Pedro de Montes Vilaf ranca do Bierzo- (Quintana Prieto 1971: 402, 403-4, 404-5, 407, 408-9, 412, 412-3, 414-5, 415-6, 418, 418-9, 422-3, 427-8, 430-1, 431-2, 433, 433-4, 434-5, 435-6, 436-7, 439-40, 440, 443-5, 445-6, 446-7, 447-8), no cartulario de Santa María de Carracedo Penf errada- (Martínez Martínez 1997) e no tombo de San Martín de Castañeda ${ }^{6}$ \& anabria- (Rodríguez González 1970: 246, 252-3, 253-4, 255-6, 256-7), dos que dá conta Boullón (2004: 5-46). Amais, na busca de documentación para crear o que será o corpus de estudo da miña tese de doutoramento, incluímos 8 textos máis que presentan trazos lingüísticos orientais. Trátase de documentos recollidos en coleccións documentais de mosteiros e catedrais: do mosteiro de Carrizo (Casado Lobato 1983), do Arquivo da Catedral de Zamora (Martín 1982), do mosteiro de San Andrés de Vega de Espinareda L eón- (Gómez Bajo 1993) e do Arquivo Diocesano de Astorga (Cavero Domínguez et alii 2001). Hoxe os documentos que se recollen nestas edicións custódianse en diferentes arquivos da Península, dato que ofrecemos no anexo xunto con outro tipo de información catalográfica.

A seguir presentamos un mapa coa localización xeográfica dos centros monacais e catedralicios citados:

5. Para un estudo deste texto remitimos ao artigo de Luz Méndez, "Un texto da franxa oriental no Tombo das viñas de Ribadavia", publicado neste mesmo volume.

6. Na documentación recollida neste cartulario aparece o topónimo Castañeira, que empregaremos sempre, salvo cando nos refiramos ao título da obra, en que reproduciremos Castañeda. 


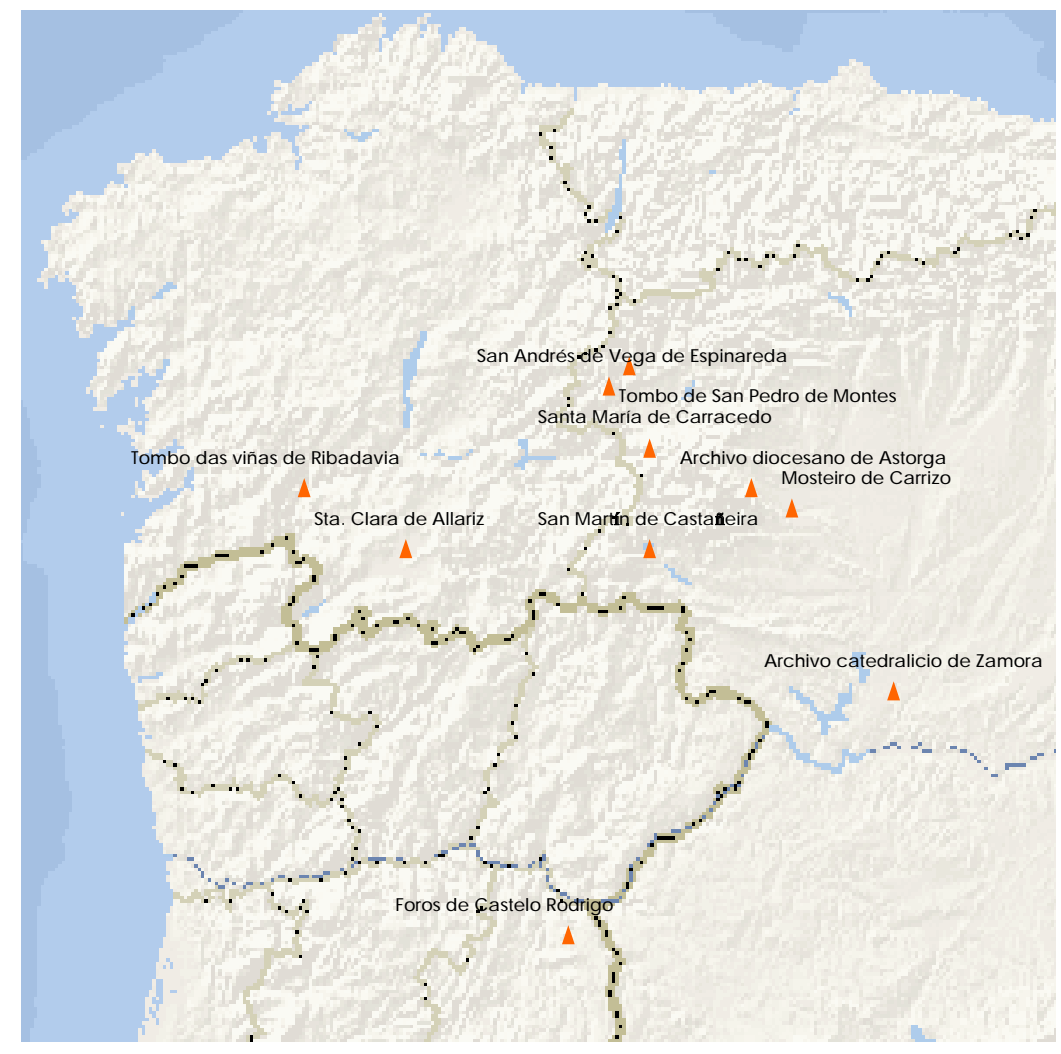

Cómpre destacar que a meirande parte dos documentos deste corpus foron localizados en coleccións documentais de fóra de Galicia, excepto o coñecido como tombo das viñas de Ribadavia, pertencente aos fondos do mosteiro de Melón, hoxe custodiado no arquivo da Catedral de Ourense, e o documento de 1244, pertencente aos fondos do convento de Santa Clara de Allariz e custodiado no Arquivo Provincial de Ourense.

\subsection{Traducións de tratados xurídicos}

Entre a primeira metade do século XIII e os tres primeiros terzos do século xIv fixéronse en Galicia versións galegas de textos latinos e casteláns. Algunha, como xa apuntamos presentan trazos astur-leoneses. Verbo desta actividade, son ben significativas as palabras de Lorenzo (1998: 125-6): 
[]. os textos galegos son de grande utilidade e moi dignos de ter en conta, pois ofrécennos casos de tradición directa e indirecta e permítennos falar da transmisión e da circulación dos textos pola Península e da inertercomunicación entre Castela, Galicia e Portugal.

2.1.1 Contamos cun fragmento de seis folios do Forum Iudicum ${ }^{7}$, que data do primeiro terzo do século XIII, publicado por López Ferreiro (1895[1975]: 695-710) nunha edición en que ofrecía o texto latino e o romance. O editor xa indicaba a dubidosa pertenza dese romance á literatura galega: "traducción que en el lenguaje difiere bastante de la oficial y corriente, y es dudoso si más bien debe inventariarse entre los monumentos de la literatura gallega, que entre los de la castellana". Efectivamente, polos trazos que presenta o texto, está escrito en leonés (Lorenzo 2000: 400) e contén unha copia do Fuero Juzgo leonés. Monteagudo (1994b: 177) fai fincapé nas deficiencias que presenta a edición de López Ferreiro, hoxe imposible de emendar dado que o manuscrito está ilocalizable.

A obra no seu conxunto é un código de validez territorial que fai unha síntese entre o dereito romano e o consuetudinario propio do pobo godo; o rei Recesvinto promulgou este texto no ano 654, para promover a unificación xurídica do reino. En concreto, os fragmentos que conservamos tratan sobre o matrimonio e o divorcio, a sucesión e herdanza e o dereito penal.

2.1.2 As Flores de Dereito son unha tradución da obra castelá Flores de Derecho (1235-1252) de Xacobe das Leis, que Pensado (1974-1975: 121), atendendo ás características paleográficas e lingüísticas, datou arredor do derradeiro decenio do século XIII ou comezos do seguinte. Só se conserva unha parte pertencente ao libro $\mathrm{I}^{8}$ que presenta as características lingüísticas do galego exterior: do galego-leonés (Lorenzo 2000: 396).

A obra, dirixida ao futuro Afonso x, recolle as leis máis importantes do dereito romano coa finalidade de que o príncipe puidera solucionar os preitos seguindo as pautas marcadas polos expertos na materia; no fragmento que se conserva en galego-leonés, recóllese a actuación dos avogados e procuradores, o curso dos preitos e dos emprazamentos que se deben facer, os xuízos entre pais e fillos e as acusacións entre irmáns.

7. Do Libro III, os títulos $5^{\circ}$ e $6^{\circ}$, do Libro IV, o título $1^{\circ}$ e do Libro VII, os títulos $1^{\circ}, 2^{\circ}$ e $5^{\circ}$ (López Ferreiro 1895[1975]: 698).

8. Do Libro I: as leis III está incompleta- e IV do título II, os títulos III, IV e v completos, e das leis I e II do título vi (Pensado 1974-5: 123-8). 
2.1.3 Do Fuero Real (1252-1255) de Afonso x tamén temos unha versión, Foro Real, que para Pensado (1974-5: 104-5) está escrita en galego-portugués:

El texto base está teñido de leonesismos, quizás, piensan los editores, por haber sido escrito en la región zamorana. Esas mismas características pueden observarse en la traducción del fragmento, bien por influjo del texto traducido, cosa posible, bien por la naturaleza bilingüe del traductor y de la zona en donde ésta se habrá hecho: el Bierzo. Lo único que no parece muy viable es suponer lo escrito para una comunidad lingüística que entremezcle ambos ingredientes (gallego y leonés) en la proporción que aquí se presentan. Nos inclinamos a creer que lo único que refleja el fragmento in es una continua fluctuación entre dos sistemas fruto de un traductor bilingüe para el que ambos son igualmente familiares y aunque su propósito es el de traducir un texto al gallegoportugués, con frecuencia se olvida de ello...

Con todo, logo da lectura deste texto comprobamos que a lingua en que foi redactado é o galego-leonés, como recolle Lorenzo (2000: 396):

Este texto está escrito coas características lingüísticas do galego exterior, en galego-leonés, e non se pode cualificar de "galaico-portugués", nin ver impericia no traductor, nin pensar que os leonesismos xa estaban no texto castelán que se traduce como suxire Pensado.

Só se conserva un folio 9 procedente do Bierzo e custodiado no Archivo Provincial de León. Esta versión forma parte do manuscrito en que se recolle a versión das Flores de Dereito, polo tanto a datación é a mesma.

O rei Sabio mandou unificar no Fuero Real as leis existentes no seu tempo; esta obra, outorgada inicialmente para a cidade de Valladolid, consta de catro libros divididos en títulos, e cada título está estruturado en leis, nos cales se recolle o dereito tradicional e consuetudinario: o libro I, ao que pertence o folio conservado en galego-leonés, trata da santa Trindade e da fe católica, do rei, dos que non obedecen o mandato real, da garda das cousas da santa Igrexa, das leis, do oficio dos alcaldes, escribáns públicos, voceiros, procuradores e dos preitos.

9. Libro I, títulos x (dende a metade da lei XI ata a última) e xI (dende a lei I ás dúas terceiras partes da IV) (Pensado 1974-5: 122-3). 
2.1.4 Despois da obra anterior, o rei Afonso fixo a primeira versión das Partidas (1256-1265). Consérvanse fragmentos traducidos ao galego da Primeira, Terceira, Cuarta, Quinta, Sexta e Sétima Partida ${ }^{10}$. Da Primeira consérvanse dous fragmentos, e a identidade lingüística do segundo deles de mediados do século XIV— ten sido discutida. Transcribrimos os dous primeiros parágrafos:

Ley .xlviii. Como el predicador pode a las vezes aspera-/mente, pero cõ mesura e nõ con vanagloria, a los que sermonar?. / Castigar pode el predicador a las vezes asperamẽte en su predica-/ciõ; pero devto fazer cõ mesura, ca por el castigo desmesurado nõ / sse enmenda tãbẽ la vida de los omes como por el outro, nẽ fazẽ a / seus mayorales: ante fincã como querelosos dellos, tenendo que lles / dan mayor pẽna que non deviã aaver... (Askins et alii 1997: 28).

O primeiro estudoso que o tirou á luz, Oviedo y Arce (1916: 75), opinaba que as formas discordantes das galegas se debían á tradución feita por un monxe con dificultades ao emanciparse do orixinal:

[].. en el fragmento que hoy publicamos de Las Partidas, no hay rastro de leonesismo. [...] nuestro texto está formado por la simple yuxtaposición de voces y giros gallegos y castellanos, y de que todas sus formas se pueden reducir a estos tres grupos: formas gallegas, abundantes; formas exclusivamente castellanas, escasas; y formas comunes, muy numerosas, según conviene al primer período de formación de ambos romances [...] un monje de un monasterio gallego, del último tercio del siglo XIII, que no acertó siempre a emanciparse de la influencia del original (Oviedo y Arce 1916: 75).

Máis tarde, Askins et alii (1997: 24-25) cualificárono como unha versión galega con erros:

10. Da Primeira Partida, dous fragmentos: o primeiro contén a lei 10 do título XIX e as leis 1 á 5 do título xx; o segundo, contén as leis 48 á 53 do título v. Da Terceira Partida, dous fragmentos: o primeiro, da lei 18 ata, aproximadamente, a 40 do título II at lgunhas ilexibles; o segundo, da lei 19 á 26 tamén do título II. Da Cuarta Partida, dous fragmentos: o primeiro, de dous folios, contén as leis 9 á 19 do título XVIII e a lei 1 do xIx; o outro, as leis 1 á 6 do título xxvII. Da Quinta Partida, un fragmento con varios folios: lexibles as leis 48 á 52 e 59 á 67 do título v, as leis 3 á 5 do título vi e as leis 4 á 7 do título vir. Da Sexta Partida, nun fragmento dun folio, as leis 12 á 17 do título vil e o epígrafe e dúas liñas do VIII, as leis 3 e 4 do título XIV, as leis 1 e 2 do Xv, a 26 do XVI, as catro primeiras do XVII e a primeira do XVIII. Da Sétima Partida, nun fragmento con dous folios, as leis 7 á 15 do título Ix (Dias 2001: 275-276, Lorenzo 2000: 397-9). 
O responsable desta versión, extremadamente descoidado, tenta trasladar ó galego un texto que estaba á súa disposición en castelán. Utiliza formas galegas nas que as vocais medias tónicas latinas non mostran ditongación (morde, morte, torto, pode, corpo, cegos, fossen, medo,...), pero ó seu lado figuran formas ditongadas que deixan ve-la orixe castelá do texto (rruegue, viene, cielo...); mesmo aparecen a pouca distancia mola e muola. Móstrase algo máis coidadoso con respecto ó tratamento dos ditongos decrecentes, que adoita conservar ó xeito galego (outro, ou, leygos, dereyto, maneyra, queyra...), coa presencia de vocais nasalizadas (bõa, algũa...) ou coas formas do posesivo (seu(s), sua(s), aínda que tamén aparece $s u$ ), pero non é quen de evitar castelanismos evidentes como yo, mio ou Dios, e mesmo chega a alterna-la voz cuello con pescoo. Tampouco pode evita-la aparición abondosísima das formas do artigo $l o(s), l a(s)$ e el ou a forma verbal $s a$ lie. Observamos tamén algún caso de confusión entre os grafemas que corresponden ás sibilantes africadas (justiza, justia ).

No entanto, para Lorenzo (2000: 397) está escrito nunha "versión galegoleonesa".

As Partidas presenta unha división en sete partes, en que se tratan as sete parcelas fundamentais do dereito: o eclesiástico, o político e administrativo, o procesual e xudicial, o dereito da familia, o de obrigacións e contratos, o de sucesión e o penal. O fragmento que nos ocupa trata dos prelados e das súas tarefas.

2.1.5 No ano 1959 Cintra recollía nun volume unha serie de foros pertencentes a catro vilas Gastelo Rodrigo, Castelo Melhor, Alfaiates e Castelo Bom- da rexión de Riba-Coa, con dous denominadores comúns: seren do século XIII e pertenceren ao reino de León ata a súa incorporación a Portugal. A lingua en que están escritos é unha combinación entre galego e leonés; di Cintra (1959: 502, apud Mariño Paz 1998: 161-169):

[]. os sistemas lingüísticos entre os quais oscila a linguagem dos Foros de Castelo Rodrigo são o galego-português e um tipo de leonês a que não são estranhos certos traços originàriamente castelhanos, normais na linguagem de textos redigidos nos fins do séc. XIII.

Os foros que se recollen neste volume forman parte das compilacións medievais de dereito consuetudinario. Foron concedidos polo rei Afonso IX e son foros locais para estas catro vilas, que conformaron un territorio que pertenceu ao reino de León ata que foi unido a Portugal logo do tratado de Alcañices. Inscríbense no período galego-leonés e están divididos en oito libros, en que se recollen leis administrativas, civís, procesuais, etc. entre ou- 
$\operatorname{tras}^{11}$, pero todas destinadas a establecer unhas normas lexislativas que serviran para regular a vida dos habitantes desta localidade.

Estes textos xurídicos, sobre todo o Foro Real e as Partidas, constitúen unha fonte de información valiosísima para o exercicio do notariado, e este feito é o que explica a necesidade de facer traducións a outros romances; era preciso que as leis procedentes de Castela se aplicasen, para un maior cumprimento, na lingua da comunidade. Nelas recóllese información sobre a maneira de facer unha carta, de redactar o documento, o número de notarios que teñen que intervir, o prezo que o notariado ten que cobrar por cada carta, o valor das minutas, a autenticidade das copias, o número de copias que se poden sacar dun documento, etc. Polo tanto, trátase dun ars notariae para os profesionais da escrita.

\subsection{Documentos notariais}

Outra fonte de interese para o estudo da sociedade, da historia e, por suposto, da lingua durante a Idade Media está formada polos textos notariais, de carácter público ou privado, que se conservan en moitos arquivos da nosa comunidade e, como indicamos, tamén fóra dela. Entre a nosa tipoloxía textual destacan os preitos, cartas de venda, doazóns, etc.

No tocante ao conxunto de 49 documentos pertencentes a diversas coleccións documentais, recollemos nesta gráfica o número de textos rexistrados en cada unha delas:

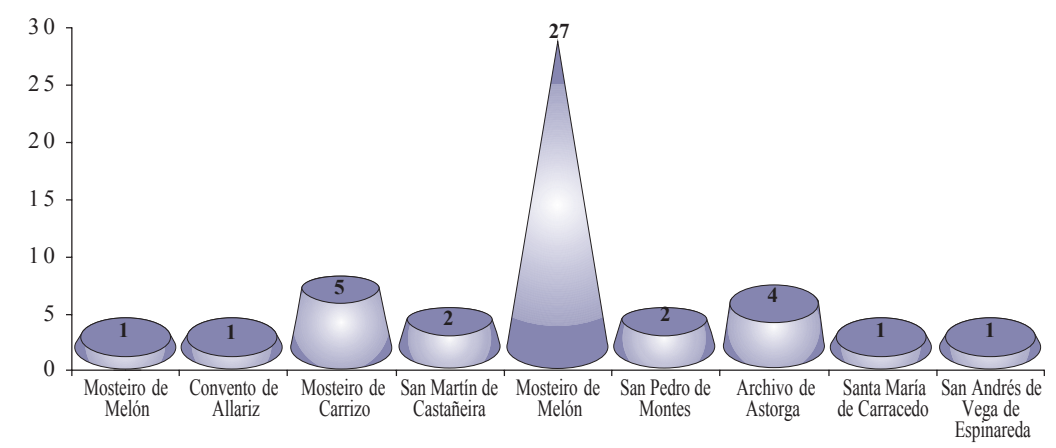

11. Citamos a seguir algúns títulos: "Qui uir porcos ena defesa. VIII", "Corral de uernes. XXXXIX", "Delas aguas das goteyras. XXXXVI", "Que non pongan barco en río. XXXVIII", "Mercadores de traperia. XXXI", "Qui de noyte andare. LXX"... 
A marxe cronolóxica en que se encadran os documentos pertencentes a cada colección recollémola na seguinte táboa, na cal indicamos o máis antigo e o máis recente do estudo:

\begin{tabular}{lcccc}
\hline & $\mathrm{n}^{0}$ de textos & máis antigo & último ata 1260 \\
\hline Mosteiro de Melón & 1 & \multicolumn{3}{c}{ [1228] } \\
\hline Convento de Santa Clara de Allariz & 1 & \multicolumn{2}{c}{1244} \\
\hline Mosteiro de Carrizo & 6 & 1258 & 1260 \\
\hline San Martín de Castañeira & 5 & 1241 & 1257 \\
\hline Catedral de Zamora & 2 & 1255 & 1258 \\
\hline San Pedro de Montes & 27 & 1243 & $\mathbf{1 2 6 0}$ \\
\hline Archivo de Astorga & 2 & 1250 & 1254 \\
\hline Santa María de Carracedo & 4 & 1245 & & 1251 \\
\hline San Andrés de Vega de Espinareda & 1 & & 1256 & \\
\hline
\end{tabular}

Entre [1228] e 1260 i- nclusive - nunhas coleccións existen máis textos con trazos orientais ca noutras. Quizais poderiamos xustificar isto pola presenza dalgún escribán ou notario nado ou afincado na zona fronteiriza que plasmase nos escritos a lingua que lle era próxima; estoume referindo a esa lingua híbrida da que vimos falando. Neste sentido, traballar unicamente con edicións feitas por historiadores limítanos, e moito, a nosa perspectiva de estudo; se consultásemos o orixinal quizais a similitude dos trazos da escrita, algunha corrección do texto, o tipo de letra, o sinal notarial, etc., podería orientarnos neste intento de establecer conexións entre textos dentro da mesma diocese, dun mesmo centro scriptorio e, incluso, cos centros scriptorios próximos.

Tamén debemos ter en conta que no noso corpus recollemos cartularios e tombos, é dicir, compilacións de documentos feitas a posteriori do momento da escrita; cómpre termos isto en consideración á hora de focar o noso interese nos trazos lingüísticos, pois é moi posible que un documento presente características diferentes cando está feito a partir dunha copia ou, pola contra, dun orixinal. A isto xa se referiu Pensado (1983: 44) cando dicía que o abade Marcos Pérez, encargado da copia do Becerro de San Pedro de Montes, non merecía moitos aplausos polo seu traballo de copista ${ }^{12}$.

Polo de agora, e cinguíndonos aos datos que nos transmiten os propios textos, sabemos que o Tumbo Viejo de San Pedro de Montes foi confecciona-

12. O propio editor deste tombo destacaba: “la transmisión de los textos se nos presenta defectuosísima. A la destacada decadencia del latín, se unieron aquí la ignorancia y la impericia del copista, resultando de todo ello unos textos lamentablemente defectuosos y deficientes. Hay que tenerlo en cuenta al hacer la lectura y estudio de los documentos" (Quintana Prieto 1971: 78). 
do entre os séculos XIII-XIV, probablemente polo citado abade Marcos Pérez que se encargou da copia tras a ocupación do seu cargo en 1286 (Quintana Prieto 1971: 17). Dos 27 textos que se rexistran, só en 10 aparece o nome do escribán ${ }^{13}$. A conclusión máis fiable que tomamos destes datos é que o antropónimo Johannes que aparece en tres documentos, dous de 1251 e un de 1252?, para referirse á persoa que executou a escrita, pode corresponder ao mesmo escribán.

Dos documentos do Cartulario de Santa María de Carracedo fixo unha copia manuscrita en 1792 o frade Fernando Juárez (Martínez Martínez 1997: IX, vol. I); polo tanto, non debemos deixar de pensar na man do copista tamén nestes textos. Dos catro seleccionados, un ten indicación do escribán Ruy Martiniz e dous do notario ${ }^{14}$; son de xuño de 1251 e van asinados por Johan Rodriguiz, que a xulgar polo que se recolle no documento, exerceu a notaría no concello de León.

No resto das coleccións coas que traballamos os documentos son orixinais, polo tanto non hai que pensar nas posibles influencias da man dun copista. Do Cartulario de San Martín de Castañeda (Rodríguez González 1973: 2) recollemos cinco textos no noso corpus, e só temos noticia de tres escribáns diferentes ${ }^{15}$ : Fernando, Fernandus e Migael Fernandez.

Nos catro documentos da colección diplomática do mosteiro de Carrizo (Casado Lobato 1983) aparece o nome das persoas que os escribiron ${ }^{16}$ : Fernan Perez, Iohan Thomas e Iohan Perez este último é o autor de seis textos diferentes; tres deles forman parte dun documento de marzo de 1260 e os outros tres forman parte doutro de abrilm aio de 1260 .

$\mathrm{Na}$ colección de Astorga (Cavero et alii 2001) temos noticia dos escribáns Dominicus Petrus e Fernan Iohanis ${ }^{17}$, mentres que no único texto que

13. "esta carta fu fecha per manu de Fernan Perez" (1243-marzo), "Petrus Roderici scripsit" (1245), "Johannes Garcia, presbiter, qui notuit" (1251-maio), "Johannes notuit" (1251-maio), "Fernandus Pelagii, qui notuit" (1251-outubro), "Johannes presbiter notuit" (1252?-novembro), "Martinus me fecit" (1255-novembro), "Fernandus Dominici monachus hanc cartam notuit" (1257-setembro), "Petrus Petri, scripsit" (1258-agosto), "Petrus notuit" (1259-febreiro), "Roy Perez scripsit" (1260xullo) e "Johan Johannes, scripsit" (1260-novembro).

14. "Ruy Martiniz escrivi" (1250), "Johan Rodriguiz, notario e jurado del conceylo de León qui notuit" (1251-xuño-18) e "Qui presentes los mismos y el mismo notario de la antecedente -sic. (1251-xuño-18)".

15. "Fernando el escriuan" (1241), "Migael Fernandez clerigo que escriuio ela outorgacion" (1251), e "Frater Fernandus notauit" (1252).

16. "Fernan Perez notuit" (1258-novembro), "don Iohan Thomas notuit" (1259-xaneiro), "Iohan Perez qui notuit" (1260-marzo; doc. 2), "Iohan Perez notuit" (1260-marzo-26; doc. 3), "Iohan Perez notuit" (1260-marzo; doc. 4), "Iohan Perez notuit" (1260-abril-23 e maio-8; doc. 1), "Iohan Perez notuit" (1260-abril-23 e maio-8; doc. 2), "Iohan Perez notuit" (1260-abril-23 e maio-8; doc. 3).

17. "Fernan Iohanis la screuio" (1250-decembro-27) e "Dominicus Petrus notuit" (1254-agosto-10). 
recollemos da documentación do mosteiro de San Andrés de Vega de Espinareda (Gómez Bajo 1993) é o notario Martinus, quen estampa o seu sinal ${ }^{18}$.

Os dous documentos procedentes de Zamora (Martín 1982) non dan noticia do autor.

Desta análise concluímos que os notarios non coinciden entre os repertorios documentais do noso corpus e neste caso, sen o coñecemento do sinal, non podemos afirmar a relación, no caso de existir, entre Fernan Iohanis e o notario de Santiago Fernando Iohannis (exerceu de 1226 a 1292), do que nos fala Bouza Álvarez (1960: 618-9). No noso intento por sabermos máis destes homes que escribiron nunha lingua en que conviven trazos galegos e astur-leoneses, consultamos a base de datos da Sección de Onomásti$\mathrm{ca}^{19}$ do Instituto da Lingua Galega (ILG) e comprobamos que cadran nos mesmos anos algúns nomes de notarios que nos aparecen a nós con notarios localizados no tombo de Lourenzá (Rodríguez González / Rey Caíña 1992: 11-324); Petrus Roderici aparece nun documento de San Pedro de Montes de 1245 e nun de Lourenzá de 1246. De todos modos, cómpre destacar que as cadeas onomásticas dos notarios que temos son tan frecuentes ao longo da Idade Media que podemos falar de homonimia entre os individuos portadores e, como consecuencia, non nos aclaran moito esta investigación.

Da procedencia xeográfica destes personaxes tampouco sabemos nada, pois o único caso algo esclarecedor é o de "Johan Rodriguiz, notario e jurado del conceylo de León", pois indícase o lugar onde desempeñaba o traballo este profesional. De seguro que todos eles escribían un romance que lles viña imposto pola súa propia fala e polo esquecemento paulatino dos modelos latinos.

\section{Algunhas CARACTERÍsticas lingüísticas dos teXtos}

Como contrapunto da uniformización lingüística que presentan as composicións trobadorescas galego-portuguesas ${ }^{20}$, os textos notariais ofrecen maior riqueza para o estudo lingüístico, pois a meirande parte- teñen data e indican o lugar da redacción. A pesar disto, debemos afrontar este estu-

18. "(signo) Martinus" (1256-xuño-15).

19. Proxecto que se desenvolve no ILG e que segue as liñas do programa Patrom (Kremer 1997 / Cano González 2004).

20. A propósito disto, recordemos o dito por Tavani no seu discurso de ingreso na Academia Galega (2004: 13) "non creo na existencia de linguas híbridas na literatura medieval; a hibridación lingüística nos textos medievais [literarios] resulta ser en todo caso o resultado dun disfrace efectuado por copistas ou executores de orixe diferente da dos autores". 
do con cautela por mor da existencia dunha scripta determinada, aprendida por moitos escribáns e notarios nas escolas monásticas ou baixo as directrices dun ensinante (Díaz e Díaz 1975).

Recollemos deseguido unhas liñas dun dos textos manexados, que excluímos do noso estudo por considerar que as características lingüísticas que presenta non o adscriben dentro do hibridismo lingüístico ao que nos vimos referindo:

[...] Saban todos ommes que eu, Don Fernando abbade de Sant Pedro de Montes, con consello del convento desse mismo monesterio, facemos cambia con vosco Ruy Garcia, cavallero en Oreyam. Damus vos una nossa terra que jaz en Baetadiello, so carrera, e outra sobre carrera, e determina e la de so carrera con vosco Ruy García per todas partes, ye e la sobre carreyra determina con sancta Maria de una parte e de la outra parte per lo diviso de la villa (1256-maio; TSPedroMontes, doc. no 332, p. 432-3).

Porén, este parágrafo que segue é parte doutro documento, no cal se observan unha serie de trazos na lingua que son de interese para a nosa análise:

[...] Sabian elos que son agora como los que an de seer, que eu Pedro Martínez et mea moler Maria Fernandez hazemos tal preito al abade don Uiuian de San Martin de Castaneira et a todol conuento de esse logar, del casal que foi de Fernando Arias el freire que auia en Ponte el que dizen del Mato, quita el abade el de cabe la eglisia por ele a Pedro Martiniz et sua moler, per tal preito que laian elos et depois sous filos et sous netos et todeme que deles uener, pero se tal tempo uener que aquela herdade queiran uender uenda ermano a ermano \& non a outre se non al monasterio de San Martin et non seia posto preito a la herdade qual se les quisieren mais dos omes bonos desse monesteiro uenan a esse logar et filen dous da uezindade et apreenna et asi seia uenduda [...].. (1241; TCastañeda, doc. $\mathrm{n}^{\circ}$ 191, p. 246).

A continuación, sen deternos moito, e seguindo a Cintra (1959), a Rafael Lapesa (1998) e a García Arias (1995) faremos unha aproximación \#ni camente nos textos notariais, entre os que excluímos o texto de [1228] por ser estudado noutro artigo deste volume- a dous trazos lingüísticos que suscitaron o noso interese e que, logo da selección e estudo do corpus, son os que se repiten con maior frecuencia na documentación.

3.1.2 Un dos fenómenos é a evolución dos grupos -ct- e -ult- latinos e, para o seu estudo, escollemos as formas "dictu,-a" "factu,-a", para o primeiro e "multu,-a", para o segundo grupo. Fixemos unha busca destas formas nos nosos textos e o resultado foi o seguinte: 
a) a vocalización en -it: dito- $a$, feito- $a$ é a solución maioritaria nos documentos de Castañeira, Carracedo e Espinareda, con 19, 3 e 4 ocorrencias, respectivamente. O grupo -ult- con vocalización do $l$ implosivo só o localizamos en dez casos: oito nos documentos de San Pedro de Montes e en dous en Castañeira.

b) a palatalización en - $c h$ : dicho- $a$, fecho- $a$ é menos frecuente e o maior número de ocorrencias rexístrase nos textos de Carrizo ( 7 ocorrencias) e San Pedro de Montes (10). As formas mucho- $a$ só as rexistramos en dez casos nos documentos de San Pedro de Montes.

Estas dúas evolucións alternan nas formas feycho, feicho, presentes no tombo de San Pedro de Montes, que podemos encadrar nunha etapa de evolución espontánea eit->ch. Con todo, cómpre destacar (Lapesa 1998: 50) que só se conservan na parte occidental de fala asturiana. Observamos a aparición tamén das grafías latinas — dicto- $a$, facto- $a$ - , que son as maioritarias de maneira rechamante nos documentos de San Pedro de Montes.

García Arias (1995: 632) fala do avance que presentan as formas palatalizadas dende o século xIII no astur-leonés; esta mesma idea apúntaa Lapesa (1998: 50) cando indica que esta palatalización é de influencia castelá, autóctona de León.

Polo tanto, as formas galegas con ditongación do grupo -ct- son as máis frecuentes.

É cando menos curioso que nos documentos de San Pedro de Montes estas evolucións non sexan parellas nestes dous grupos, cousa que nos fai pensar na posible intervención do copista, o abade Marcos Pérez.

\begin{tabular}{l|c|c|c|c|c|c|c|c|c|}
\cline { 2 - 9 } & \multicolumn{2}{|c|}{ grupo latino -ct-/-ult- } & \multicolumn{3}{|c|}{$>$-it- } & \multicolumn{3}{c|}{$>$-ch- } \\
\cline { 2 - 9 } & dicto-a & facto-a & multo-a & dito-a & $\begin{array}{r}\text { feito-a/ } \\
\text { feyto-a }\end{array}$ & $\begin{array}{l}\text { muito-a/ } \\
\text { muyto-a }\end{array}$ & dicho-a & fecho-a & mucho-a \\
\hline Carrizo (4) & - & 1 & - & 2 & - & - & - & 7 & - \\
Castañeira (5) & - & 4 & - & $\mathbf{1 4}$ & 5 & 2 & - & - & - \\
Zamora (2) & $\mathbf{2}$ & - & - & 1 & 1 & - & 1 & 1 & - \\
Montes (27) & $\mathbf{4 1}$ & 10 & - & 6 & 5 & 8 & - & 10 & 10 \\
Astorga (1) & - & - & - & $\mathbf{2}$ & - & - & - & 1 & - \\
& & & & & & & & feicha & \\
Carracedo (4) & - & $\mathbf{2}$ & - & 1 & $\mathbf{2}$ & - & - & - & - \\
Espinareda (1) & 1 & 1 & - & - & $\mathbf{4}$ & - & - & - & -
\end{tabular}

A seguir presentamos unhas gráficas que sintetizan a información do cadro precedente: 
GRUPO LATINO -ct-/-ult->-it->-ch-

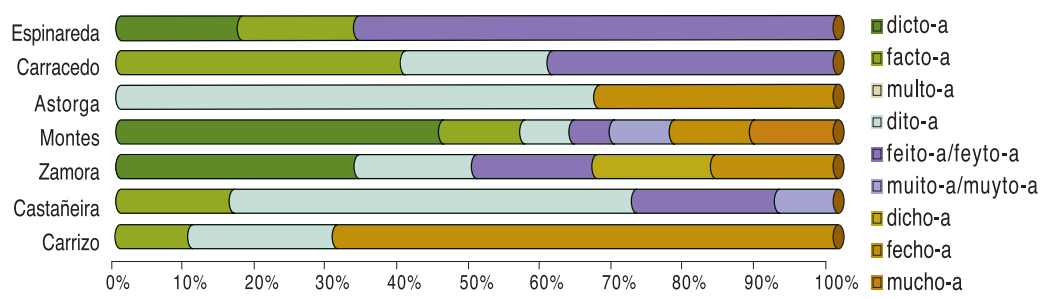

3.2.2 No pronome persoal é de destacar a 1P singular, pois hai alternancia entre a forma galega eú $\mathbf{a}$ s veces con $b$ - non etimolóxico-, a do castelán e astur-leonés occidental yo e a do ditongo analóxico, dominante no occidente leonés, you; desta alternancia xa falou Boullón (2005: 59-60); nos outros documentos, temos sempre eu:

[...] pouco e mucho quanto yo hy ey, ata la menor piedra que hy a. Et you Johan Migaellez outrasi dou al monesterio de Sant Pedro de Montes quanta herdad tivey de mia hermana Maria Migaellez, que la mandó meter por la sua anima. Esta herdad que eu dou al monesterio teniala you $[\ldots]$.

A forma que presenta máis ocorrencias é a galega $e u$, seguida de yo, de you e, finalmente, da latina ego. Esta alternancia, xunto coa numerosa presenza de eu en textos de San Pedro de Montes fainos pensar, novamente, na intervención do copista Marcos Pérez.

\begin{tabular}{l|c|c|c|c|c|c|}
\cline { 3 - 4 } & \multirow{2}{*}{ forma latina ego } & \multicolumn{3}{|c|}{ eu/heu } & \multirow{2}{*}{ yo } & \multicolumn{2}{|c|}{ you/iou } \\
\cline { 3 - 4 } \cline { 6 - 7 } & & $\mathrm{eu}$ & heu & & you & iou \\
\hline Carrizo (4) & - & 4 & - & $\mathbf{6}$ & - & - \\
\hline Castañeira (5) & - & $\mathbf{1 2}$ & 1 & - & - & - \\
\hline Zamora (2) & - & $\mathbf{4}$ & - & 1 & 1 & - \\
\hline Montes (27) & 1 & $\mathbf{5 9}$ & 1 & 9 & 4 & - \\
\hline Astorga (1) & - & - & - & - & - & - \\
\hline Carracedo (4) & - & $\mathbf{6}$ & 5 & - & - & - \\
\hline Espinareda (1) & - & - & - & 1 & - & - \\
\hline
\end{tabular}


EGo, Eu/HEv, Yo, You/IOU

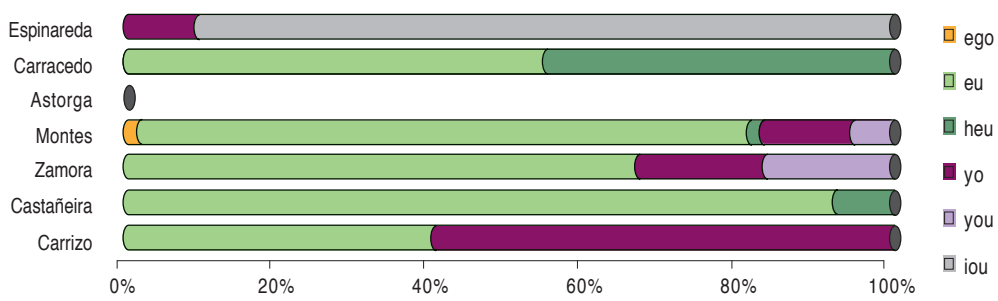

Observamos como no léxico van aparecendo formas romances que pertencen, dado o tipo de documentos, ao campo da cotidianeidade: "casas, vinnas, terras, montes arotos, por aromper, arbores, pesqueyras, molineyras". Normalmente, sobre todo nos documentos máis antigos do corpus, é na expositio onde temos máis formas en romance fronte ao protocolo e ao escatocolo, as partes do texto que os escribáns e os notarios tiñan máis aprendidas ao reproducirse, semellantes ou con pequenas variantes, na meirande parte dos documentos.

No que respecta á onomástica, conviven formas latinas de topónimos "Gallecia", "Legione" e antropónimos "Pelagius", "Martinus" con formas romances "Castela", "Castiella”, "Pai”, "Pelaiz", "Paes”, "Martino", "Martín”, "Yuannes”, etc.

\section{CABO}

A nosa intención foi facer unha achega a algúns dos textos primitivos da franxa que hoxe en día coñecemos; evidentemente, non están todos os que son e é probable que cunha análise detida dos fondos dos mosteiros da zona fronteiriza e do Archivo Histórico Nacional (AHN) poidamos sumar moitos máis e facermos un estudo detallado da lingua que durante esta época usaron os notarios e escribáns nas súas tarefas cotiás.

A partir do ano 1260, ata o que chega o noso estudo, observamos como nas coleccións documentais manexadas este hibridismo que presentan os textos notariais diminúe e vaise trazando unha escrita máis unificada, onde é menor a abundancia de trazos propiamente galegos ao tempo que se van incrementando os trazos do castelán. Polo tanto, esta situación difusa entre variedades lingüísticas non deixa de ser un estadio da lingua nunha época en que o romance, xa existente na fala, estaba agromando na escrita. Na nosa comunidade, esa uniformización lingüística quedará consolidada coa chegada do século XIv, en que aumenta considerablemente o uso da lingua galega na documentación xurídico-administrativa de Galicia. 
A Historia compostelana considera que entrar ou saír de Galicia significa pasar perfauces montium, atravesar a zona montañosa do Cebreiro, e foi isto o que pretendemos facer neste artigo: ver como era o romance durante o século XIII máis alá do Cebreiro.

\author{
ANEXO \\ REXESTO E INFORMACIÓN CATALOGRÁFICA DE DOCUMENTOS NOTARIAIS \\ ÉDITOS PRIMITIVOS DA FRANXA ORIENTAL
}

A continuación recollemos o rexesto que adaptamos á ortografía actual do galego e regularizamos os topónimos e antropónimos- e algunhas indicacións catalográficas dos documentos de carácter xurídico-administrativo da franxa oriental: a referencia do arquivo en que se encontran sem pre que nos foi posible- - e a edición en que localizamos os textos.

Para a escolla dos textos da franxa cos que traballamos, tivemos en conta unicamente unha serie de trazos diferenciais, prescindindo das solucións comúns entre o galego e o astur-leonés, así como de solucións diverxentes explicables polos diferentes estadios evolutivos. Aínda así, atopámonos cunha grande falta de precisión á hora de determinarmos os trazos que permiten diferenciar unha e outra fronteira lingüística.

O trazo máis salientable do leonés que tivemos en conta para foi a diton-

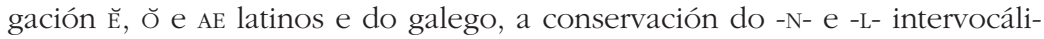
cos, os presentes etimolóxicos/analóxicos de TENEO, -AM, VENIO, -AM e a solución dos pronomes persoais de primeira persoa.

\title{
Mosteiro de Melón: tombo das viñas de Ribadavia
}

[1228]: "Investigación dos xuíces dos bens de varias ordes en Ribadavia e San Estevo por orde do rei don Afonso IX".

Arq.: ACOu, Arquivo de Melón, leg. 22, caixa 9, nº 1.

Ref:: Cambón 1957, vol. Iv, nº 224 -dátao entre 1188 e 1230; Gallego 1986: 160

—dátao nos anos de reinado de Afonso IX.

Obs.: Ferro Couselo (1957:8) fai referencia a un texto e, polas indicacións que dá, parece tratarse do tombo das viñas "Entre los pergaminos procedentes del antiguo monasterio de Melón, tan ligado a la historia de esta villa existe un apeo, hecho alrededor de 1228, por mandato de Alfonso Ix de León, en el cual se nos ofrece una relación de los dueños de las casas y heredades que había en la villa.... 


\section{Tombo de San Pedro de Montes (Vilafranca do Bierzo-Ponferrada)}

1243-marzo: "Elvira González véndelle a don Xoán, abade de San Pedro de Montes, propiedades en Vilacedeira e Fabeiro".

Arq.: ADA, TVM, no 304, fol. $74 \mathrm{r}$.

Ref.: TSPedroMontes, doc. $\mathrm{n}^{\circ}$ 298, p. 402.

1245: "Don Crimente dóalle a San Pedro de Montes as súas herdades en Valtuille". Arq.: ADA, TVM, $\mathrm{n}^{\circ}$ 375, fol. 93.

Ref:: TSPedroMontes, doc. no 300, p. 403-4.

1247-marzo-8: "Don Xoán, abade de San Pedro de Montes, afóralles un terreo en Vilar a Pai Estévez e á súa muller Mariña Pérez".

Arq.: ADA, TVM, $\mathrm{n}^{\circ} 28$, fol. 11.

Ref:: TSPedroMontes, doc. $\mathrm{n}^{\circ}$ 301, p. 404-5.

1251-maio: "Don Pedro, abade de San Andrés de Espinareda, afóralles un terreo en Rubiana a Martín Fernández e á súa muller Mariña Rodríguez".

Arq.: ADA, TVM, $\mathrm{n}^{\circ}$ 68, fol. 20.

Ref.: TSPedroMontes, doc. $\mathrm{n}^{\circ}$ 304, p. 407.

1251-maio: "Don Pedro, abade de San Andrés de Espinareda, afóralles varias posesións en Rubiana a Xoán Martíns e á súa muller María Marcos".

Arq.: ADA, TVM, n 69 , fol. 20.

Ref.: TSPedroMontes, doc. $\mathrm{n}^{\circ}$ 305, p. 408-9.

1252-abril: "Don Gonsalvo, abade de San Pedro de Montes, afóralles varias posesións en Viobra a Fernán Pérez e á súa muller Mariña Sánchez".

Arq.: ADA, TVM, n 65, fol. 19r.

Ref.: TSPedroMontes, doc. $\mathrm{n}^{\circ}$ 310, p. 412.

1252-maio: "Don Gonsalvo, abade de San Pedro de Montes, afóralles varias posesións en Saguaza a Pedro Fernández e á súa muller María Eans".

Arq:: ADA, TVM, $\mathrm{n}^{\circ}$ 56, fol. 12.

Ref:: TSPedroMontes, doc. $\mathrm{n}^{\circ} 311$, p. 412-3.

1252?-novembro: "Don Gonzalo, abade de San Pedro de Montes, véndelles unha herdade en Saguaza a María Pérez e aos seus fillos Gonzalo Muniz e Maior Muniz".

Arq.: ADA, TVM, $\mathrm{n}^{\circ}$ 55, fol. 12.

Ref:: TSPedroMontes, doc. $\mathrm{n}^{\circ} 313$, p. 414-5. 
Obs.: O editor propón esta data por ser o último ano en que foi abade do mosteiro de San Pedro de Montes don Gonzalo (Quintana Prieto 1971: 514).

1252?-novembro: "Dona Xusta doa propiedades a San Pedro de Montes en Vilar de Xudeus".

Arq.: ADA, TVM, n ${ }^{\circ} 27$, fol. $15 \mathrm{r}$.

Ref:: TSPedroMontes, doc. $\mathrm{n}^{\circ}$ 314, p. 415-6.

Obs.: O editor indica que este texto está mal datado ao non ter en conta o valor da x con vírgula (Quintana Prieto 1971: 416).

1253-xullo-13: "Dona Mariña e o seu marido don Afonso véndenlle a don Gonsalvo, o abade de San Pedro de Montes, as súas herdades en San Pedro de Trones". Arq: : ADA, TVM, $\mathrm{n}^{\circ}$ 90, fol. $15 \mathrm{r}$.

Ref:: TSPedroMontes, doc. $\mathrm{n}^{\circ}$ 316, p. 418.

1253-novembro: "Don Xoán Johanis, arcipreste, dálle ao mosteiro de San Pedro de Montes as propiedades que posúe en Vale e en Castrelo".

Arq.: ADA, TVM, $\mathrm{n}^{\circ}$ 312, fol. 77.

Ref:: TSPedroMontes, doc. $\mathrm{n}^{\circ} 317$, p. 418-9.

1255-xaneiro: "Rodrigo Rodríguez véndelle ao mosteiro de San Pedro de Montes as posesións de Pumares".

Arq.: ADA, TVM, $\mathrm{n}^{\circ} 21$, fol. 9r.

Ref:: TSPedroMontes, doc. $\mathrm{n}^{\circ}$ 322, p. 422-3.

1255-novembro: "Don Fernando, abade de San Pedro de Montes, afóralles a Gonzalo Núnez e á súa muller, María Sánchez, unha herdade en Saguaza”.

Arq.: ADA, TVM, $\mathrm{n}^{\circ}$ 54, fol. 16r.

Ref:: TSPedroMontes, doc. $\mathrm{n}^{\circ} 327$, p. 427-8.

1256-maio: "O abade don Fernando dálles foros aos seus vasallos en Torienzo".

Arq.: ADA, TVM, $\mathrm{n}^{\circ}$ 183, fol. 49r.

Ref.: TSPedroMontes, doc. $\mathrm{n}^{\circ}$ 330, p. 430-1.

1256-maio: "Tereixa Fernández e Maior Fernández, co seu pai Fernán Pérez, véndenlle a don Fernando, abade de San Pedro de Montes, as súas propiedades alén do río Sil, en Vilacideira e no Fabeiro".

Arq.: ADA, TVM, $\mathrm{n}^{\circ}$ 303, fol. $74 \mathrm{r}$.

Ref:: TSPedroMontes, doc. $\mathrm{n}^{\circ}$ 331, p. 431-2. 
1256-xuño: "Pero Moniz, xuíz de Valdeorras, restitúelle ao convento de San Pedro de Montes propiedades en Bobaños, San Cristovo e Quereño".

Arq: : ADA, TVM, no 29, fol. 11.

Ref.: TSPedroMontes, doc. $\mathrm{n}^{\circ}$ 333, p. 433.

1256-xullo: "Ruí Fernández Pico fai un preito e avinza con don Fernando, abade de San Pedro de Montes, sobre unhas propiedades en Turienzo a cambio doutras en Borrenes".

Arq.: ADA, TVM, n ${ }^{\circ}$ 182, fol. 49.

Ref:: TSPedroMontes, doc. $\mathrm{n}^{\circ} 334$, p. 433-4.

1257-febreiro: "Ruí Moniz véndelles ao abade don Fernando e ao convento de San Pedro de Montes todas as herdades que ten en Quereño".

Arq.: ADA, TVM, $\mathrm{n}^{\circ} 25$, fol. 10.

Ref:: TSPedroMontes, doc. $\mathrm{n}^{\circ} 335$, p. 434-5.

1257-maio: "Maior Pedres, que foi muller de Alvar Núnez de Turienzo, véndelle a don Fernando, abade de San Pedro de Montes, as súas propiedades de Sancha Fernández en Turienzo".

Arq.: ADA, TVM, $\mathrm{n}^{\circ}$ 186, fol. 50r.

Ref:: TSPedroMontes, doc. $\mathrm{n}^{\circ}$ 336, p. 435-6.

1257-maio: "Guter Fernández Piquelos e outros véndenlle as súas propiedades en Turienzo a don Fernando, abade de San Pedro de Montes".

Arq.: ADA, TVM, no 184, fol. 50.

Ref:: TSPedroMontes, doc. $\mathrm{n}^{\circ} 337$, p. 436-7.

1257-setembro: "García Eans de Benavente dóalle a don Fernando, abade de San Pedro de Montes, a súa cabana en Morales de Rei".

Arq.: ADA, TVM, no 166(bis), fol. 45.

Ref:: TSPedroMontes, doc. $\mathrm{n}^{\circ} 339$, p. 439-40.

1258-abril: "María Johannis e o seu marido véndenlle ao mosteiro de San Pedro de Montes os bens que posúen en Quintanilla".

Arq.: ADA, TVM, $\mathrm{n}^{\circ} 358$, fol. 88r.

Ref.: TSPedroMontes, doc. $\mathrm{n}^{\circ}$ 340, p. 440.

1258-novembro: "Guter Pérez véndelle a don Fernando, abade de San Pedro de Montes, propiedades en Turienzo".

Arq.: ADA, TVM, $\mathrm{n}^{\circ}$ 188, fol. 50r.

Ref.: TSPedroMontes, doc. $n^{\circ}$ 343, p. 443. 
1259-xaneiro: "Ruí Peláiz e a súa muller véndenlle ao mosteiro de San Pedro de Montes as súas propiedades de Borrenes".

Arq.: ADA, TVM, no 337, fol. 83.

Ref:: TSPedroMontes, doc. no 344, p. 443-5.

1259-febreiro: "Pedro Peláez, monxe de San Pedro de Montes, dálle ao mosteiro as súas posesións en Cesterna, Valdescayos e Manzanedo".

Arq.: ADA, TVM, $\mathrm{n}^{\circ} 211$, fol. 53r.

Ref:: TSPedroMontes, doc. $\mathrm{n}^{\circ} 345$, p. 445-6.

1260-xullo: "Ruí Pérez véndelle ao mosteiro de San Pedro de Montes todos os seus bens en Arantigua".

Arq.: ADA, TVM, $\mathrm{n}^{\circ}$ 220, fol. 56.

Ref:: TSPedroMontes, doc. $\mathrm{n}^{\circ} 346$, p. 446-7.

1260-novembro: "Don Fernando, abade do mosteiro de San Pedro de Montes, dálles a García Martíns e á súa muller, Orraca Peláiz, a casaría de Sobradelo".

Arq.: ADA, TVM, $\mathrm{n}^{\circ} 30$, fol. 11.

Ref:: TSPedroMontes, doc. $n^{\circ} 347$, p. 447-8.

\section{Allariz}

1244-xaneiro: "Carta de foro de dona Toda aos homes de Vilaboa (Sanamede de Castromarigo, Veiga do Bolo)".

Arq.: AHPOu, Santa Clara de Allariz. Carp. C-6/ perg. $\mathrm{n}^{\circ} 1(15 \times 23 \mathrm{~cm})$.

Ref:: DocDevOurense, vol. I, no 1, p. 13-14 € on foto nas pp. 18 e 19.

Obs.: Boullón (2004: 18) indica que neste texto "están en latín as cláusulas penais e o escatocolo" pero non indica que se trata dun texto con trazos leoneses; esta característica tampouco a apunta Souto Cabo (2003: 439), que indica que o texto "pode sugerir algum tipo de influxo do ámbito castelhano-leonês, inclusive perceptível a nível lingüístico"; en cambio, Lorenzo (2004b: 39) di "que se trata dun texto híbrido, con partes en latín e outras en romance, e as súas características lingüísticas son propias do galego-leonés, non do castelán-leonés."

\section{Carrizo}

1258-novembro: "Marcos e a súa muller, Marina Pérez, véndenlle a Pedro Díaz dúas terras na vila de Fresno".

Arq.: AMC. Perg. $\mathrm{n}^{\circ} 324$ (170x95 mm).

Ref:: CDCarrizo, doc. $\mathrm{n}^{\circ} 328$, p. 353. 
1259-xaneiro: "Domingo Guereyro e o seu irmán Gómez véndenlle a don Bartolomé e á súa muller, Marina Guilelmez, seis terras na Bañeza e Pereje”.

Arq.: AMC. Perg. $\mathrm{n}^{\circ} 330(140 \times 280 \mathrm{~mm})$.

Ref:: CDCarrizo, doc. $\mathrm{n}^{\circ} 333$, p. 358-9.

1260-marzo:

"2) Pedro Pérez e a súa muller, María Yuanes, véndenlle a Pedro Gil e á súa muller, María Crementez, dúas viñas no bago da Mata, baixo a campá de San Andrés (no termo de Matalobos do Páramo)".

Arq.: AMC. Perg. $\mathrm{n}^{\circ} 351(575 \times 230 \mathrm{~mm})$.

Ref:: CDCarrizo, doc. $\mathrm{n}^{\circ}$ 356, p. 388-91.

1260-marzo-26:

“3) Pedro Gabriel e a súa muller, María Yuanes, véndenlles a Pedro Gil e á súa muller, María Crementez, unha viña no bago da Mata, baixo a campá de San Andrés (no termo de Matalobos do Páramo)".

1260-marzo:

“4) Mioro Fernández, co consello do seu marido, Pedro Paez, véndelles a Pedro Gil e á súa muller, María Crementez, dúas viñas no bago da Mata, baixo a campá de San Andrés (no termo de Matalobos do Páramo)".

1260-abril-23/maio-8:

"1) Don Iuanes de Ribas véndelles a Pedro Gil e á súa muller, María Crementez, dúas viñas no bago da Mata, baixo a campá de San Andrés e don Miguel, coa súa muller, dona María, véndelles tamén aos mesmos compradores unha viña no dito lugar".

Arq.: AMC. Perg. $\mathrm{n}^{\circ} 370(500 \times 170 \mathrm{~mm})$.

Ref:: CDCarrizo, doc. $\mathrm{n}^{\circ} 371$, p. 407-9.

"2) Domingo Andrés e a súa muller, Marina Yuanes, véndenlles a Pedro Gil e á súa muller, María Crementez, unha viña no bago de La Mata, baixo a campá de San Andrés".

“3) Doña Iusta, cos seus fillos e co consello do seu marido, don Aparicio, véndelles a Pedro Gil e á súa muller, María Crementez, unha viña no bago de La Mata, baixo a campá de San Andrés". 


\section{Tombo de San Martín de Castañeira (Sanabria)}

1241: "Pedro Martíns e a súa muller, María Fernández, fan un pacto co mosteiro de San Martín de Castañeira e co seu abade Viviano sobre un casal situado en Ponte del Mato".

Arq.: AHN. Clero. San Martín de Castañeda. Leg. 2338, perg. nº 43 (150x140 mm). Ref:: TCastañeda, doc. $n^{\circ} 191$, p. 246.

1251: "Elvira de Prada dóalle ao mosteiro de San Martín de Castañeira varias herdades: dous casais en San Lourenzo, o que lle correspondía no igrexario e na igrexa de Iares, Paradela e Vilar de Eguas".

Arq.: AHN. Clero. San Martín de Castañeda. Leg. 3566, perg. n 13.

Ref:: TCastañeda, doc. $\mathrm{n}^{\circ}$ 197, p. 252-253.

1252: "Elvira Pédrez dóalle ao mosteiro de San Martiño de Castañeira varios casais e cabanas en Ime, Paradela, San Lourenzo e Vilar de Eguas".

Arq.: AHN. Clero. San Martín de Castañeda. Leg. 3566, perg. $n^{\circ} 14$.

Ref:: TCastañeda, doc. $\mathrm{n}^{\circ} 198$, p. 253-4.

1257: "O abade Viviano, de San Martín de Castañeira, dálle ao cabaleiro Vivian Díaz e á súa esposa o usufruto do casal que foi de Xoán Pérez de Vascóns, preto da igrexa de San Vicente".

Arq.: AHN. Clero. San Martín de Castañeda. Leg. 3566, perg. nº 17 (200x170 mm); partido por $a b c$.

Ref:: TCastañeda, doc. nº 200 , p. 255-6.

1257-abril: "Pedro Álvarez dóalle ao mosteiro de San Martín de Castañeira todas as súas herdades en Casoio, coa condición de que o mosteiro o ampare".

Arq.: AHN. Clero. San Martín de Castañeda. Leg. 2339, perg. $n^{\circ} 51$.

Ref:: TCastañeda, doc. n 201 , p. 256-7.

\section{Zamora}

1255-setembro-20 -Mayorga: "Rodrigo González declara que recibiu de F. e de Sancho de Toro tres mil marabedís que lle foron asignados polo rei na martiñega dese lugar".

Arq.: ACZ, leg. 15, $2^{\text {a }}$ parte, doc. 16.

Ref:: CDACZamora, doc. $\mathrm{n}^{\circ} 152$, p. 125.

1258: "Rodrigo Peláez e a súa muller, Elvira Rodríguez, renuncian ao século; Rodrigo renuncia ao dereito a vivir coa súa muller así como a calquera outro que 
puidera ter sobre a súa persoa, comprométese a entrar na Orde de Santiago e autoriza a Elvira a que faga o mesmo nesta e noutra orde".

Arq.: ACZ, leg. 16, $2^{\mathrm{a}}$ parte, doc. 37 (incluído na sentenza do preito promovido polo marido para obrigar a convivir á súa muller; a sentenza é do 7 de maio de 1259).

Ref.: CDACZamora, doc. nº 164, p. 135-6.

\section{Archivo Diocesano de Astorga}

1250-decembro-27-Astorga: "Concordia entre o bispo de Astorga, Pedro, e os seus vasalos da colación de San Román de Val de San Lorenzo"

Arq.: ADA, Cámara episcopal. Carp. III, doc. 71. Perg. orix. (195x280 mm).

Ref:: CDADAstorga, doc. $\mathrm{n}^{\circ}$ 58, p. 110-2.

1254-agosto-10-Piedras Albas: "Don Pedro, bispo de Astorga, entrégalle ao clérigo Juan Miguelez a casa de Santa María de Filiel por 60 soldos de renda anual. Cando a deixe, en vida ou morte, a metade será para o bispo e da outra metade poderá dispoñer libremente"

Arq.: ADA, Cámara episcopal. Carp. III, doc. 65. Perg. orix. (125x190 mm).

Ref:: CDADAstorga, doc. $\mathrm{n}^{\circ}$ 76, p. 119-120.

\section{Cartulario de Carracedo (Ponferrada)}

1245-febreiro: "Elvira Rodríguez dóalle ao seu marido unha terra en Valtuille".

Arq.: ADA, ms. do XVIII, fol. $342, \mathrm{n}^{\circ} 5$.

Ref:: CDCarracedo, doc. no 429, p. 299.

1250-marzo: "Elvira Fernández véndelle ao mosteiro unhas casas en Astorga".

Arq.: ADA, ms. do xvIII, fol. 229v, no 29.

Ref:: CDCarracedo, doc. no 452, p. 316.

1251-xuño-18: "García González empeña a súa herdade de Cela e Fombasallá".

Arq.: ADA, ms. do XVIII, fol. 435, $\mathrm{n}^{\circ} 3$.

Ref:: CDCarracedo, doc. ${ }^{\circ} 465$, p. 324.

1251-xuño-18: "García González dóalle ao mosteiro todas as súas herdades de Fombasallá, Cela, Parada e outros lugares, estando prisioneiro nas Torres de León”.

Arq.: ADA, ms. do XVIII, fol. 436, $\mathrm{n}^{\circ} 4$.

Ref:: CDCarracedo, doc. no 466, p. 325. 


\section{San Andrés de Vega de Espinareda (León)}

1256-xuño-15: "O abade do mosteiro de Espinareda concédelles foros aos poboadores de Otero de Langre".

Arq.: AHNS. Clero, perg. MSAV. Espinareda, Carp. 835, doc. II. (190x185 mm).

Ref:: CDVegaEspinareda, doc. $\mathrm{n}^{\circ} 11$, p. 24-5.

Ademais destes documentos atopamos entre as coleccións manexadas e na Colección documental del monasterio de Santa María de Carbajal (10931461) (Domínguez Sánchez 2000) un conxunto de documentos que presenta as características propias dos textos astur-leoneses, pero teñen como trazo galego máis destacado o uso do pronome de primeira persoa eu; e aínda que esta única peculiaridade non nos pareceu abonda para incluílos na nosa escolla, cremos que pode ser de interese indicar as referencias destes textos.

\section{Tombo de San Pedro de Montes (Vilafranca do Bierzo-Ponferrada)}

1247: "Avinza en Orellán entre o mosteiro e Pedro García”.

Arq.: ADA, TVM, n 351, fol. 87.

Ref:: TSPedroMontes, doc. doc. $\mathrm{n}^{\circ}$ 302, p. 405-6.

1252-outubro: "Pai Pérez e a súa muller Sancha Gómez véndenlle a herdade de Valdecanada a don Gonsalvo, abade de San Pedro de Montes".

Arq: : ADA, TVM, no 299, fol. 73r.

Ref.: TSPedroMontes, doc. $\mathrm{n}^{\circ} 312$, p. 413-4.

1253?: "Don Martín Fernández e a súa muller, dona Azenda, dóanlle os seus bens en Vilar de Judeos, San Pedro de Trones, Quereño e outros lugares ao mosteiro de San Pedro de Montes".

Arq.: ADA, TVM, n $\mathrm{n}^{\circ}$ 31, fol. 11r.

Ref:: TSPedroMontes, doc. $\mathrm{n}^{\circ} 315$, p. 416-7.

Obs.: O editor indica que esta hipotética data foi deducida pola mención que se fai ao abade Gonzalo e a dona Azenda, ambos os dous presentes en documentos durante este ano (Quintana Prieto 1971: 417).

1255-xaneiro: "O abade don Fernando dálle a Diego Johannes unha muiñeira que posuía no mosteiro en Saguaza".

Arq.: ADA, TVM, n 43, fol. 14.

Ref.: TSPedroMontes, doc. $\mathrm{n}^{\circ}$ 321, p. 421-2. 
1256-marzo: "O abade don Fernando dálles a casaría de Ycedo a Diego Martíns e á súa muller María Pérez".

Arq.: ADA, TVM, $\mathrm{n}^{\circ} 32$, fol. 11.

Ref.: TSPedroMontes, doc. no 329, p. 429-30.

1256-maio: "Don Fernando, abade de San Pedro de Montes, permútalle uns bens a Ruí García, cabaleiro en Orellán".

Arq.: ADA, TVM, n 353 , fol. 87r.

Ref:: TSPedroMontes, doc. n $^{\circ} 332$, p. 432-3.

1258-agosto-16: "Johan Fernández véndelle ao mosteiro de San Pedro de Montes todo o que ten en Torienzo".

Arq.: ADA, TVM, n ${ }^{\circ} 187$, fol. 50r.

Ref:: TSPedroMontes, doc. $\mathrm{n}^{\circ} 342$, p. 442.

\section{Santa María de Carbajal (León)}

1244-maio: "Dona Loba e os seus fillos véndenlle ao mosteiro de Santa María de Carbajal un solar sito en Grisuela del Páramo, por dous marabedís".

Arq.: ASMC, doc. 70. Perg. orix. (150x165 mm).

Ref.: Colección documental de Santa María de Carbajal, doc. n 162, p. 248-9.

\section{Carrizo}

1250-xuño: "Xoán Nariz e a súa muller María Pérez, xunto con Xoán Iohannis e a súa muller, Marina Iohannis, véndenlles a don Pedro Março e a súa muller, María Pelayz, unha terra no Hospital".

Arq.: AMC. Perg. $\mathrm{n}^{\circ} 260(165 \times 155 \mathrm{~mm})$.

Ref:: CDCarrizo, doc. $\mathrm{n}^{\circ} 263$, p. 284-5.

1251-agosto: "A abadesa de Carrizo, dona Sancha Moniz, co consello e consentimento da comunidade, dálle ao cóengo de Astorga, Diego Gil, unha "praza" na vila de Astorga, dentro dos seus muros, para que constrúa tres casas".

Arq.: AMC. Perg. $\mathrm{n}^{\circ} 277(145 \times 205 \mathrm{~mm})$.

Ref:: CDCarrizo, doc. $\mathrm{n}^{\circ} 281$, p. 303-4.

1252-maio: "Testamento de dona Elvira Arias".

Arq.: AMC. Perg. $\mathrm{n}^{\circ} 281$ (165x230 mm).

Ref:: CDCarrizo, doc. $\mathrm{n}^{\circ} 285$, p. 307-8. 
1260-febreiro:

“1) Don Migahel e a súa irmá irmá Mioro véndenlles a Pedro Gil e á súa muller, María Crementez, unha viña en Mata de Lobos (Matalobos do Páramo)".

Arq:: AMC. Perg. no 345 (270x95 mm).

Ref.: CDCarrizo, doc. n 352 , p. 380-2.

“2) Don Salvador e a súa cuñada dona Marina véndenlles a Pedro Gil e á súa muller, María Crementez, unha viña en Mata de lobos".

1260-febreiro-20: "Bartolomé e a súa muller, dona Estefanía, véndenlles a Pedro Gil e á súa muller, María Crementez dúas viñas en Matalobos".

Arq.: AMC. Perg. $\mathrm{n}^{\circ} 348(130 \times 225 \mathrm{~mm})$.

Ref:: CDCarrizo, doc. $\mathrm{n}^{\circ} 353$, p. 382-3.

\section{Zamora}

1242-novembro-11 -Día de san Martín-: "Don Xoán, capelán da raíña e abade do mosteiro de Santa María de Arvás, véndelle a Domingo Pérez unhas casas xunto ao mosteiro e recibe por elas herdades valoradas en corenta marabedís".

Arq.: ACZ, leg. 31, $3^{\text {a }}$ parte, doc. 12.

Ref.: CDACZamora, doc. no 125, p. 103.

1256-xullo: "O deán e o cabido de Zamora cámbianlle a Pedro Pérez, leigo de Cubillos, unhas casas neste lugar por outras en Moreruela de Miro e por dous quiñóns de viña".

Arq.: ACZ, leg. 31, $3^{\text {a }}$ parte, doc. 13.

Ref:: CDACZamora, doc. $\mathrm{n}^{\circ}$ 159, p. 131-2.

\section{Archivo Diocesano de Astorga}

1243-abril: "Pedro Fernández e a súa muller, Teresa, véndenlle ao bispo de Astorga, Pedro Fernández, unha casa en Curillas, unha viña e dezaseis terras, por corenta marabedís"

Arq.: ADA, Cámara episcopal. Carp. II, doc. 49. Perg. (255x270 mm).

Ref.: CDADAstorga, doc. $\mathrm{n}^{\circ}$ 58, p. 96-7.

\section{Cartulario de Carracedo (Ponferrada)}

1253-maio: "Martín Domínguez véndelle ao mosteiro viñas en Cacabelos".

Arq.: ADA, ms. do XVIII, fol. $381 \mathrm{v}, \mathrm{n}^{\circ} 36$.

Ref:: CDCarracedo, doc. $\mathrm{n}^{\circ} 481$, p. 334-5. 
1253-xuño: "Miguel Domínguez véndelle a Pedro Moniz tres sortes de viñas en Robledo". Arq.: ADA, ms. do XVIII, fol. $381 \mathrm{v}, \mathrm{n}^{\circ} 37$.

Ref:: CDCarracedo, doc. $\mathrm{n}^{\circ}$ 482, p. 335.

1253-decembro: "Arias Méndez de Naraia e seu irmán, Pedro Méndez, dóanlle ao mosteiro de Carracedo a súa herdade de Cumbraos".

Arq.: ADA, ms. do XVIII, fol. 263v, $\mathrm{n}^{\circ} 7$.

Ref.: CDCarracedo, doc. $\mathrm{n}^{\circ} 485$, p. 337. 